\title{
Economic Freedom, Income Inequality and Life Satisfaction in OECD Countries
}

\author{
Johan Graafland ${ }^{1,2}$ (D) Bjorn Lous ${ }^{2}$
}

Published online: 12 August 2017

(C) The Author(s) 2017. This article is an open access publication

\begin{abstract}
Since Piketty's Capital in the 21st Century in 2014, scientific interest into the impact of income inequality on society has been on the rise. However, little is known about the mediating role of income inequality in the relationship between market institutions and subjective well-being. Using panel analysis on a sample of 21 OECD countries to test the effects of five different types of economic freedom on income inequality, we find that fiscal freedom, free trade and freedom from government regulation increase income inequality, whereas sound money decreases income inequality. Income inequality is found to have a negative effect on life satisfaction. Mediation tests show that income inequality mediates the influence of fiscal freedom, free trade and freedom from government regulation on life satisfaction.
\end{abstract}

Keywords Economic freedom - Income inequality - Life satisfaction · Mediation · Regulation - Tax freedom · Trade freedom

JEL Classification A13 $\cdot \mathrm{D} 60 \cdot \mathrm{E} 02 \cdot \mathrm{O} 57 \cdot \mathrm{P} 14 \cdot \mathrm{P} 16 \cdot \mathrm{P} 51$

\section{Introduction}

Up until now, a vast amount of literature has been produced on the variables affecting subjective well-being measures (Frey and Stutzer 2001; Dolan et al. 2008; Blanchflower and Oswald 2011). One of the research subjects which is still in its infancy, however, is the relationship between economic freedom and subjective well-being. The concept of economic

Johan Graafland

j.j.graafland@uvt.nl

Bjorn Lous

bs.lous@gmx.com

1 Department of Philosophy, CentER, Tilburg Sustainability Center, Tilburg University, P.O. Box 90153, 5000 LE Tilburg, The Netherlands

2 Department of Economics, Tilburg University, P.O. Box 90153, 5000 LE Tilburg, The Netherlands 
freedom relates to the degree of personal choice, voluntary exchange, freedom of competition, and protection of privately owned property afforded by society (Gwartney et al. 2004). Previous research has shown that economic freedom stimulates life satisfaction (Veenhoven 2000; Ovaska and Takashima 2006; Gropper et al. 2011). Graafland and Compen (2015) show that the positive relationship between economic freedom and life satisfaction is mediated by income per capita and generalized trust. Indeed, as many studies have shown, economic freedom stimulates income per capita or economic growth (Dawson 1998; De Haan and Sturm 2000; Gwartney et al. 2004; De Haan et al. 2006; Justesen 2008; Altman 2008), and other research has shown that income per capita increases subjective well-being (Stevenson and Wolfers 2008; Fischer 2008). Trust has also been shown to be dependent on economic freedom (Berggren and Jordahl 2006) as well as being a determinant of life satisfaction (Helliwell 2003, 2006; Bjørnskov et al. 2007, 2010; Oishi et al. 2011).

Another potentially important mediator between economic freedom and life satisfaction, that has not yet been researched, is income inequality, interest in which has been fueled by the publication of Piketty (2014). With data based on fifteen years of research on income and wealth inequality, he shows that both income and wealth inequality have been rising continuously since the 1980s. Sixty per cent of economic growth since the 1960s has gone to the top $1 \%$ (Piketty and Saez 2013). According to Piketty, this has been caused by a combination of market forces and economic policy. A high level of economic freedom implies, amongst other things, low marginal tax rates that provide little room for redistributive policies (Berggren 1999). According to Piketty, low taxes signal that the government does not object to excessive remuneration (also Dincer and Gunalp 2012). Economic freedom additionally includes a low level of government regulation of financial, product, and labor markets, and this may further enhance inequality by enabling those with economic power to use it to their personal benefit (Stiglitz 2012). Wilkinson and Pickett (2010) argue that inequality negatively affects physical and mental health and therefore ultimately human flourishing.

The central research question that we focus on in this paper is therefore: How does income inequality mediate the relationship between economic freedom and life satisfaction in OECD countries? In order to answer this research question, we focus on two sub questions: First, how do (different dimensions of) economic freedom influence income inequality? Second, how does income inequality affect life satisfaction? By analyzing these questions, this paper aims to extend our knowledge of the role of income inequality in the influences of various indicators of economic freedom on life satisfaction in Western countries.

This paper is structured as follows. Section 2 introduces the conceptual framework and hypotheses. Section 3 describes the data sources. Section 4 presents the results of the empirical analysis. Section 5 summarizes the main findings and discusses some policy implications.

\section{Conceptual Framework}

The real question is not whether the market economy works or not. It is whether it works the way we want it to work. Tomas Sedlacek (2012: page 319)

Equality can be based on income, wealth, consumption or any other reasonable proxy for well-being (such as job opportunities and social security). Most of the empirical research focuses on inequality of annual income, because data for other types of inequality are less 
available and less measurable (Verme 2011; Piketty 2014). Income inequality is also important for many other dimensions of human well-being (e.g. education, health, etc.). In this paper we therefore focus on income inequality within countries.

Economic freedom means that property rights are secure and that individuals are free to use, exchange, or give their property to another as long as their actions do not violate the identical rights of others (Gwartney et al. 1996). Economic freedom has several dimensions: low tax rates (small size of the government), protection of property rights (rule of law), access to sound money (hard currency), freedom to exchange goods and services internationally, and no regulatory restraints that limit the freedom of exchange in credit, labor, and product markets.

In this section we will first discuss the relationship between the various aspects of economic freedom and income inequality. Second, we describe the relationship between income inequality and life satisfaction. Finally, the overall conceptual framework is presented.

\subsection{Economic Freedom and Income Inequality}

Stiglitz (2012) argued that unfair policies and manipulation of the market through the underlying inequality in political and economic power enabled the top $1 \%$ of the income distribution to receive a disproportionate share of economic growth in the US for the last 30 years. This analysis is in line with Roine et al. (2009) who argued, using data from Atkinson and Piketty's World Top Income Database, that the high economic growth during the last decades has been mainly beneficial to rich income groups. The increase in GDP did not trickle down, something which holds equally for Anglo-Saxon and continental European countries. Yet, in contrast to the Anglo-Saxon countries, increasing trade has not led to a further increase in the very top incomes in continental Europe within the population class of the richest $10 \%$. According to Roine et al. (2009), this is due to strong labor market institutions and the equalizing role of the government.

This discussion indicates that inequality is related to government institutions and therefore to (various dimensions of) economic freedom. Some previous studies showed that economic freedom decreases income inequality in the longer run. Scully (2002) estimated that the index of economic freedom has a small but significant negative impact on the Gini index. Also, Berggren (1999) found that sustained and gradual increases in economic freedom influence inequality measures negatively. He argued that one cannot rightly claim on theoretical grounds that higher levels of economic freedom go hand in hand with higher levels of income inequality. This relationship is unclear a priori; even when redistribution falls, if the poor take advantage of changes in other variables of economic freedom (such as the protection of property rights, or increased trade liberalization) more so than the rich, inequality may decrease (Gwartney et al. 1996; De Vanssay and Spindler 1994). Hence, the freedom-inequality relationship should be empirically tested. Using four different variables for inequality, Berggren (1999) tested this hypothesis controlling for wealth and the illiteracy rate. In all regressions, he found that the lower the initial level of economic freedom and the higher the change in economic freedom, the lower the level of inequality at the end of the sample. Therefore, Berggren concluded that, for the poor, the relatively strong income-growth effect due to a positive change in economic freedom outweighs an increase in income inequality from lower redistributive policies. Berggren mentioned that trade liberalization and financial mobility drive these findings, suggesting that poor people are employed in industries that benefit more from free trade. A problem with Berggren's analysis is that he used data from 1975-1985. In this period, the economic context was 
different, especially, as explained by Piketty (2014), regarding inequality and the economic system. This diminishes the relevance of Berggren's article for the current state of the economy.

The paper by Bennett and Vedder (2013) looks at a more recent period. They found a non-linear, parabolic relationship between economic freedom and inequality, concluding that in the very long run (at least 10 years), increases in economic freedom might have a negative effect on inequality. However, they also stated that this reduction in inequality falls in the same time period as the technology boom in the 1990s, and this could mean that this finding is related to exceptional circumstances. Apergis et al. (2014) studied economic freedom and income inequality through a panel error correction model of US data over the period 1981-2004. They found that economic freedom decreases inequality both in the short and in the long run. On the other hand, Bennett and Nikolaev (2014) found that economic freedom is related to higher levels of both net and gross Gini coefficients.

In the literature, researchers have usually focused on only one of the five dimensions of economic freedom or on the aggregate index (Berggren and Jordahl 2005; Norberg 2002; Jäntti and Jenkins 2010; Berggren 1999; Gwartney et al. 2004). This is also the case with Hall and Lawson (2014), who made an overview of empirical studies using the Economic Freedom Index of Fraser Institute. They found that over two-thirds of 198 studies found a positive impact of economic freedom on well-being, while only $4 \%$ found a negative impact. However, three of the studies that did find a negative influence in the overview of Hall and Lawson concern the effect on income inequality. Hall and Lawson therefore conclude that the evidence from these studies indeed indicates that more economic freedom may come at a price of an increase in income inequality. Moreover, they did not look at the components of the index but only considered the aggregate measure. In this paper, we hypothesize that the various dimensions of economic freedom may have different, and partly opposite, effects on income inequality.

First, inequality may be positively related to tax freedom and negatively to the size of government, of which tax income is a major indicator (Berggren and Jordahl 2006). Traditionally, one of the major tasks of the government has been redistribution of income, as the 'market for charity' is usually subject to a number of failures in large societies (Schwarze and Härpfer 2002). Piketty (2014) stated that income inequality is mainly determined by tax policies. He argued that the progressivity of the tax system is an indicator of the general social morale of a society. It has an important signal function as to what is acceptable with respect to income inequality and therefore even affects income inequality before taxes (gross income inequality). Schneider (2012) argued that perceptions of the legitimacy of income inequality are important to their appreciation, which is reflected in the tax system (also Schmidt-Catran 2014). Therefore, we hypothesize that fiscal freedom increases income inequality.

Second, Norberg (2002) argued that the free market reduces inequality in the long run, because it protects the private property of all. A high quality of legal structure and security of property rights is particularly relevant for the poor, because in an economy that does not secure private property rights they are much more vulnerable than are the rich and powerful. Lack of respect of private property rights limits economic opportunities and forces the poor to restrict their economic activities to the informal economy. Only the rich elite in such a context has the power and opportunities to initiate profitable, modern economic activities. Gwartney et al. (2004) empirically studied economic freedom (as an indicator of institutional quality) in relation to cross-country income inequality. They concluded that institutional quality is very important for predicting long-term income differences, but the impact is ambiguous. 
With respect to the relationship between access to sound money and inequality, literature has indicated that inflation and inequality are positively related. The underlying reason is that low income households use cash for a greater share of their purchases (Erosa and Ventura 2002). The use of financial technologies that hedge against inflation is positively related to household wealth (Mulligan and Sala-i-martin 2000). Attanasio et al. (1998) found that the use of an interest bearing bank account is positively related to educational level and income. Inflation is therefore more costly for low income households. Although Jäntti and Jenkins (2010) found no relationship between sound money and income inequality in the United Kingdom between 1961 and 1999, other research has confirmed the positive relationship between inflation and income inequality (Beetsma 1992; Romer and Romer 1998; Easterly and Fischer 2001; Albanesi 2002). Since access to sound money reduces inflation, we hypothesize that access to sound money reduces income inequality.

Literature has also related inequality to trade openness. Cornia (2004) argued that trade openness increased within-country inequality in developing countries. The World Bank (2006) also referred to various researches showing that trade liberalization has a positive influence on wage inequality. This is confirmed by an overview article by Goldberg and Pavcnik (2007) who showed that the exposure of developing countries to international markets, as measured by the degree of trade protection, the share of imports and/or exports in GDP, the magnitude of foreign direct investment, and exchange rate fluctuations, has increased inequality in the short and medium term, although the precise effect depends on country and time-specific factors. In literature, several explanations are offered for this effect. First, the rise of China and other lowincome developing countries may have shifted the comparative advantage from low-skill to intermediate or high skill intensity and therefore increased the demand and wage for skilled labor at the expense of unskilled labor (Wood 1999). A second mechanism is skill-biased technological change. This technological change may have taken the form of increased imports of machines, office equipment, and other capital goods that are complementary to skilled labor (Acemoglu 2003). Liberalization may also have raised the demand for skilled labor, because it advantages companies that are operating more efficiently or closer to the technological frontier (Haltiwanger et al. 2004). Finally, trade liberalization has increased the prices of consumption goods (such as food and beverages) that have a relatively large share in the consumption bundle of the poor, and has decreased the prices of goods that are consumed in greater proportion by the rich (Porto 2006).

Finally, inequality may depend on the intensity of government regulation of financial, product, and labor markets. Stiglitz (2012) and Piketty (2014) argued that business and labor regulations are necessary for assuring minimal standards of living through minimum wage and health regulations. Minimum wages and other labor market regulations such as the right to be represented by unions strengthen the bargaining power of employees, raising average wages. This enables a large part of the population to gather adequate savings to deal with economic shocks. Liberalization may also lead to unequal access to the financial market (World Bank 2006). Fast liberalization and privatization allow powerful insiders to gain control over state banks (Stiglitz 2002). Important product market institutions that provide opportunities to the poor are antitrust legislation, good infrastructure and low transportation costs, and supply of information (for example by internet connections in rural areas) (World Bank 2006). 
Based on this discussion, we state five hypotheses:

H1 Fiscal freedom increases income inequality.

H2 High quality of legal system and protection of property rights decreases income inequality.

H3 Access to sound money decreases income inequality.

H4 Trade openness increases income inequality.

H5 Freedom from regulation of labor, product, and capital markets increases income inequality.

\subsection{Income Inequality and Life Satisfaction}

Although there is a quickly-increasing volume of literature about happiness in general, only a few researchers have investigated its relationship to income inequality. First of all, in a theoretical exercise, Baggio and Papyrakis (2014) found that the type of growth (propoor, pro-middle incomes, pro-rich) determines the impact of income (growth) on subjective well-being, suggesting an impact of inequality not only directly, but also through growth. Overall with respect to the direct effect, previous studies indicate that income inequality decreases life satisfaction. ${ }^{1}$ Oshio and Kobayashi (2010) found that inequality has a strong negative impact on happiness. However, the magnitude of the negative effect varies for different population groups. For example, for females and young people, the effects are stronger than for other groups. Verme (2011) found that the measure of inequality is important, and after taking account of the variations in the measurement of inequality, he found that inequality has a robust negative and significant impact on life satisfaction. Schneider (2012) found that the influence of income inequality on life satisfaction depends on cultural perceptions and social-economic preferences. If income inequality is perceived as representing high potential for social mobility, then it might have a positive effect on life satisfaction. Thus Schneider (2012) empirically confirmed the meritocracy argument, one of the central explanations for toleration of high inequality. If, however, a society considers inequality to reflect social distance, the effect on life satisfaction will be negative. This line of argument is related to the finding by Luttmer (2005) that relative consumption is an important aspect of well-being, that should not be ignored and has a negative impact in addition to the influence of absolute consumption. Finally, Hajdu and Hajdu (2014) found that income redistribution leads to increased well-being.

Apart from these papers on income inequality and life satisfaction, there is a significant amount of literature providing indirect evidence of the negative relationship between income inequality and life satisfaction by linking income inequality to various mental problems and health. The most influential source is Wilkinson and Pickett (2010), who showed that inequality negatively affects both physical and mental health in a variety of ways. A major problem with their work is that they mostly based it on correlation patterns, but have not investigated the assumed causal relationship (Simic 2012). Sturm and Gresenz (2002), after giving a strong theoretical argumentation, showed empirically how chronic medical conditions and mental ill-health can be explained through income inequality. Kahn et al. (2000)

\footnotetext{
${ }^{1}$ Only Berg and Veenhoven (2010) found that income inequality slightly increases happiness. Furthermore, Zagorski et al. (2014) found that the Gini-coefficient does not affect subjective well-being in European countries.
} 
established the link between income inequality and poor maternal health. The psychological dimensions of inequality have also been elaborated on by Lerner (2006), describing how working-class America is becoming increasingly disillusioned and frustrated about life.

Besides affecting mental health of individuals, inequality may also lower the quality of the social environment in which individuals live, which is reflected in crime figures and lack of trust. The IMF has published several reports that warned against the presumed negative social impact of inequality in the long run (Berg and Ostry 2011; Bastagli et al. 2012; Ostry et al. 2014). Similar conclusions were found by OECD (2012). All of these papers argued that the social effects of inequality are enormous, although empirical research on causal links between inequality and a variety of variables has been limited and ambiguous. Helliwell et al. (2009) found that the social environment is twice as important for happiness as income. Elgar and Aitken (2011) emphasized that inequality on a microscale leads to more violent crime. Wilkinson and Pickett (2009) presented evidence for income inequality explaining social dysfunction, whereas income level or other material standards do not. They also found that the national level of inequality is more important than regional inequality, which suggests that national trends and policies are crucial to the level of inequality and its impact on society. Finally, inequality may also reduce happiness by lowering trust. For example, Oishi et al. (2011) found that income inequality leads to a lack of trust. They also found that the impact differs for different income groups, and that it is strongest for the lowest income quintile.

Based on this literature overview, we state the following hypothesis:

H6 Income inequality reduces average life satisfaction.

\subsection{Overall Conceptual Model}

Based on Sects. 2.1 and 2.2, the model that is used can be expressed by Fig. 1.

Mathematically, the model can be described by the following equations:

$$
\begin{gathered}
\mathrm{LS}_{\mathrm{i}, \mathrm{t}}=\mathrm{a} \mathrm{II} \mathrm{I}_{\mathrm{i}, \mathrm{t}}+\sum \mathrm{b}_{\mathrm{j}} \mathrm{V}_{\mathrm{j}, \mathrm{i}, \mathrm{t}}+\sum \mathrm{c}_{\mathrm{j}} \mathrm{X}_{\mathrm{j}, \mathrm{i}} \\
\mathrm{II}_{\mathrm{i}, \mathrm{t}}=\mathrm{d}_{1} \mathrm{FF}_{\mathrm{i}, \mathrm{t}}+\mathrm{d}_{2} \mathrm{PPR}_{\mathrm{i}, \mathrm{t}}+\mathrm{d}_{3} \mathrm{SM}_{\mathrm{i}, \mathrm{t}}+\mathrm{d}_{4} \mathrm{FT}_{\mathrm{i}, \mathrm{t}}+\mathrm{d}_{5} \mathrm{FR}_{\mathrm{i}, \mathrm{t}}+\sum \mathrm{e}_{\mathrm{j}} \mathrm{W}_{\mathrm{j}, \mathrm{i}, \mathrm{t}}+\sum \mathrm{f}_{\mathrm{j}} \mathrm{Z}_{\mathrm{j}, \mathrm{i}}
\end{gathered}
$$

LS denotes life satisfaction, II income inequality, FF fiscal freedom, PPR protection of property rights, SM sound money, FT free trade and FR freedom from regulation. $\mathrm{V}_{\mathrm{j}}$ and $\mathrm{W}_{\mathrm{j}}$

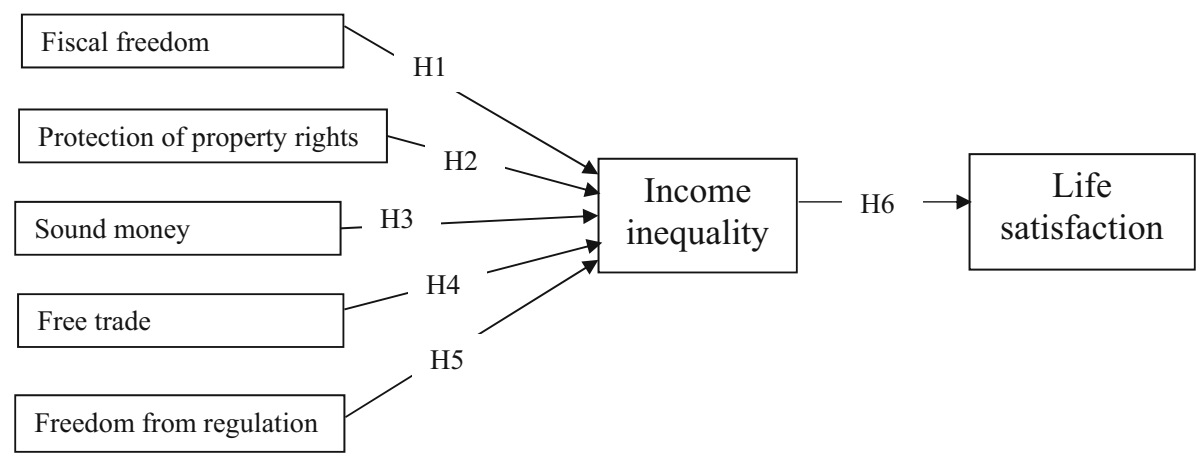

Fig. 1 Conceptual model representing hypotheses for determinants of income inequality and life satisfaction 
denote time variant control variables for life satisfaction and income inequality respectively. $\mathrm{X}_{\mathrm{j}}$ denote time invariant control variables for life satisfaction and $\mathrm{Z}_{\mathrm{j}}$ time invariant control variables for income inequality. The indices $i$ and $t$ denote country and year.

\section{Data and Methods}

\subsection{Data Sources and Measurement}

In order to test the model, we used a cross-country panel analysis for a period from 1990 till 2014. The dataset used for conducting the empirical analysis was constructed using different sources, including Veenhoven's world database of life satisfaction, the World Bank, the Fraser Institute and the Heritage Foundation. Based on these sources, we constructed a sample of 21 OECD countries, for which all variables are available that we will use throughout our analysis (Table 1).

The data for life satisfaction came from Veenhoven's World Database of life satisfaction. Life satisfaction was measured as a grade on a scale of 0-10 as an answer to the simple survey question "All things considered, how satisfied are you with your life as a whole these days?". Our focus on OECD countries somewhat reduces the range and standard deviation in life satisfaction, because OECD countries have a relatively high life satisfaction. However, the range $(5.5-8.5, \mathrm{SD}=0.65)$ is still quite substantial. An analysis of life satisfaction for all countries in the world shows that 8.5 is the maximum for all countries, whereas $66 \%$ of all countries have a life satisfaction score higher than 5.50 $(\mathrm{SD}=1.40)$.

The most common measure for income inequality is the Gini-coefficient that calculates inequality over the complete range of the income distribution, usually after taxes. Using the Solt database, we tested both for gross Gini and for net Gini coefficients. Theoretically, one would expect that the net Gini coefficient is more relevant than the gross Gini coefficient as a mediator in the relationship between economic freedom and life satisfaction. Our focus on OECD countries also reduces the range and SD in income inequality. For example, whereas the gross Gini coefficient ranges from 32.1 to 56.6 in our sample ( $\mathrm{SD}=4.3$ ), the range becomes $24.7-74.3$ ( $\mathrm{SD}=10.1$ ) when the sample is extended to all countries in the world (for which such data are available). Comparing the standard deviations, the focus on OECD countries thus reduces the standard deviation for life satisfaction (from 1.40 to 0.65 ) in equal measure as it does reduce the standard deviation in income inequality (from 10.1 to 4.3 ).

The data for economic freedom were taken from the Fraser Institute and the Heritage Foundation that provide alternative estimates of the five dimensions of economic freedom that we include in our analysis. ${ }^{2}$ As the measurement of institutional characteristics is inherently difficult (Dawson 1998), we tested the convergence between the indicators of the Fraser Institute and Heritage Foundation for each of the dimensions of economic freedom separately. Table 2 shows that for Fiscal freedom, the Protection of property rights, and Freedom from regulation, the Spearman correlation coefficient is very significant and strong. For Free trade the coefficient is still very significant but rather low. For Sound Money, the coefficient is neither significant nor strong. This is probably caused by the different indicators that Fraser Institute and Heritage foundation use to measure Sound

\footnotetext{
${ }^{2}$ For an overview of sub components of the five indices, see Appendix 1.
} 


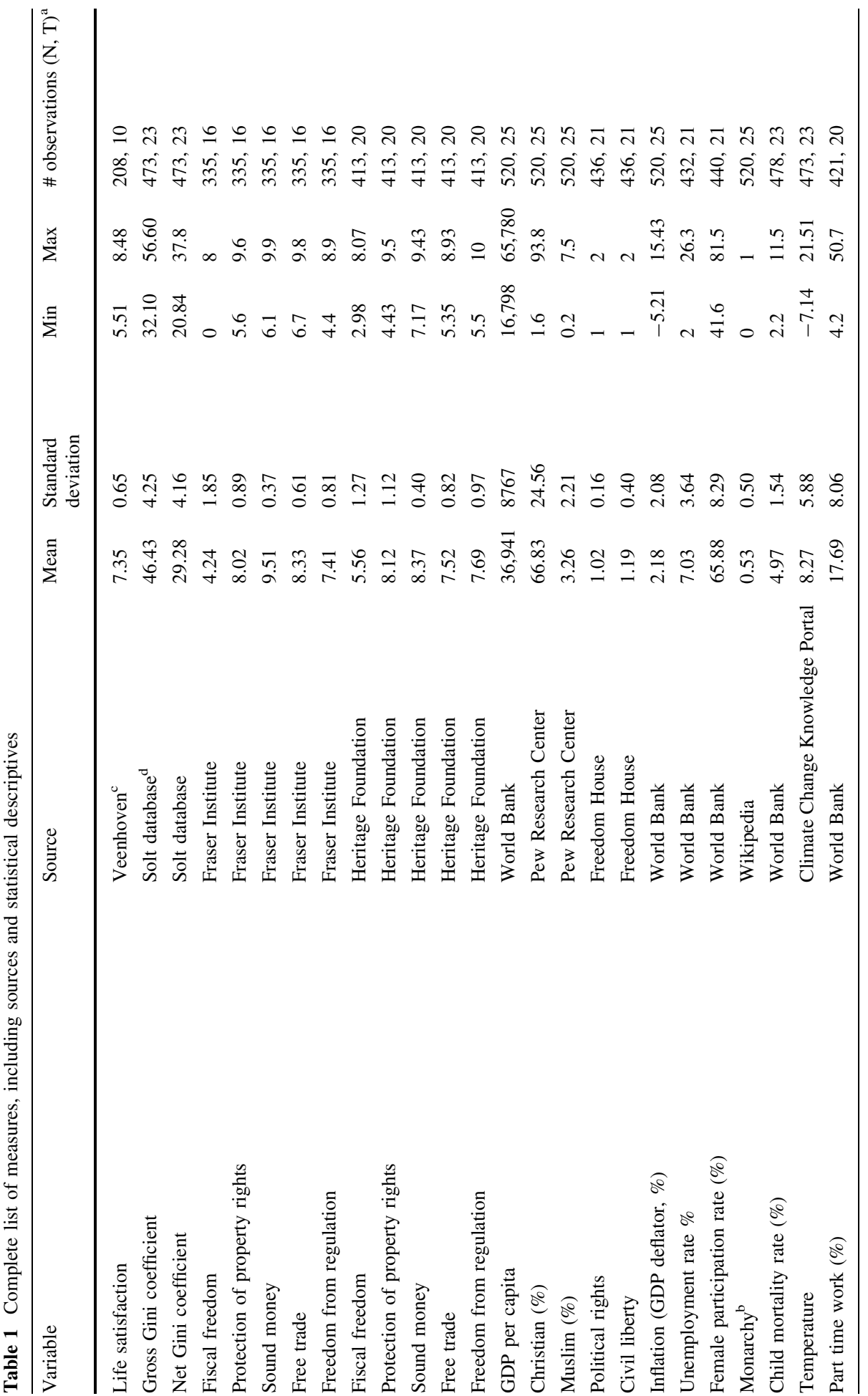




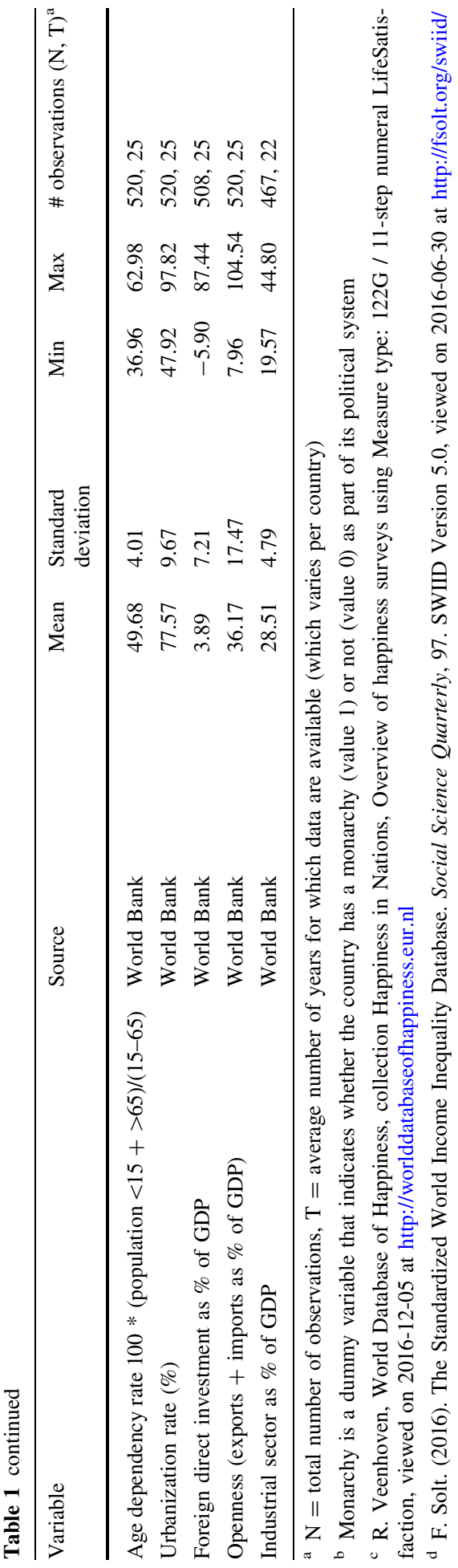


Table 2 Correlation coefficients for five dimensions of economic freedom between indicators from Fraser Institute and Heritage Foundation

\begin{tabular}{lllll}
\hline Fiscal freedom & Protection of property rights & Sound money & Free trade & Freedom from regulation \\
\hline $0.66^{* * *}$ & $0.79 * * *$ & 0.08 & $0.21 * * *$ & $0.69 * * *$ \\
\hline
\end{tabular}

Spearman correlation coefficients

$* p<0.05$; ** $p<0.01$; *** $p<0.001$

Money (see Appendix 1). Besides (average) inflation (which is used by both institutes), the Heritage Foundation uses price controls (which is not used by Fraser institute), whereas the Fraser institute uses money growth, standard deviation of inflation and freedom to own foreign currency accounts (which are not used by the Heritage Foundation). Also the weighting of these indicators is very different between the Fraser Institute and the Heritage foundation.

\subsection{Control Variables}

Income per capita is an important determinant of life satisfaction, because it raises consumption, health, education level, and employment (Dolan et al. 2008; Frey and Stutzer 2001; Di Tella and MacCulloch 2010). Although research by Easterlin et al. (2011) and Di Tella and MacCulloch (2010) has cast doubt on the long term effect of income per capita on subjective well-being, Stevenson and Wolfers (2008) and Fischer (2008) found a positive correlation between subjective well-being and income that is significant and robust among countries, within countries, and across time. Therefore, we included income per capita as a control variable in the regression analysis of life satisfaction. GDP per capita was measured in purchasing power parity at constant, international dollars. In order to deal with the non-linearity of the relationship between life satisfaction and income per capita, the natural logarithm of GDP per capita was used (lnGDPcap) (Graafland and Compen, 2015). Diener et al. (2010) found that life evaluation measures for well-being are equally dependent on income per capita for poor and rich countries, once the logarithm of income per capita (instead of the absolute income per capita) is used.

Besides income per capita, we included several other control variables that are often used in research in life satisfaction (Ovaska and Takashima 2006; for an extensive list, see also Bjørnskov et al. 2008) and for which data are available during the estimation period. Time variant controls include inflation, unemployment rate, female participation rate and child mortality. Time invariant controls include religion (Christianity, Muslim), political rights, civil liberty, monarchy, and average temperature.

For income inequality, we used a set of control variables that are common in research relating economic freedom to income inequality (see Bennett and Nikolaev 2014). Based on their list of control variables, we included foreign direct investment, age structure of population, urbanization rate, share of the labor force employed in the industrial sector and openness as time variant controls. In addition, we looked for other variables in recent literature such as part time work as time variant control and religion, political rights, civil liberty and a regional dummy for Scandinavian countries as time invariant controls (Leigh 2006; Steijn and Lancee 2011; Bergh and Bjørnskov 2014; Barone and Mocetti 2016). 


\subsection{Econometric Issues}

In the regression analysis, we used a panel estimation technique and tested for fixed and random effects to control for unobserved heterogeneity. The fixed effect technique implicitly assumes that values across countries cannot be compared. While there is an ongoing discussion as to whether reported levels of life satisfaction are consistent throughout different cultures, this assumption is very strong and not necessarily justified. First of all, Frey and Stutzer (2001) argued based on psychological evidence that previous research indicated that "reported subjective well-being is a satisfactory empirical approximation to individual utility". Both Veenhoven (2000) and Diener and Suh (1997) pointed out that aggregate subjective well-being scores are consistent enough to be meaningfully comparable across cultures. In addition, Helliwell et al. (2009) found that despite cultural differences, the same limited set of variables is valued in comparable ways across the world. Also, our sample consists of fairly similar countries with comparable similar standards of living. Previous literature identified that only Latin American countries significantly deviated from average life satisfaction levels when corrected for income levels. In order to test for fixed effects, we performed Hausman tests. This test is used to evaluate the consistency of an estimator and can also be applied to differentiate between fixed effects and random effects models. The random effects model is preferred under the null hypothesis due to higher efficiency, whereas the fixed effects model is preferred if the null hypothesis is rejected. The test results showed that the null hypothesis is accepted (see below). Therefore, we use a random effects model.

In order to control for correlation between the residuals for life satisfaction and income inequality, we used the conditional mixed process (CMP) estimator with robust standard errors to test the hypotheses. CMP fits a large family of multi-equation estimators. It fits seemingly unrelated systems. Since the models can be multi-equation, random effects at a given level are allowed by default to be correlated across equations. Conditional means that the model can vary by observation. This is an advantage for our model, since we have more observations for estimating the equation for income inequality than for the equation of life satisfaction.

A potential econometric problem that may bias the results is simultaneity bias. Whereas there is no theoretical rationale to assume inverse causality from life satisfaction on income inequality, there might be reverse causality from income inequality on economic freedom. Several researchers, such as Scully (2002) and Carter (2006), have assumed that economic freedom is exogenous to income inequality. But Berggren (1999) argued that a poor majority could, in a democracy by voting and in a dictatorship by rebelling, try to institute freedom-reducing measures if it believed that this would increase their equality situation. His test results indicated, however, no serious problem of endogeneity. Other studies simply accepted the fact that causality cannot fully be empirically proven (Roine et al., 2009) or ignored it at all (Jäntti and Jenkins 2010). Following Bennett and Nikolaev (2014), in our analysis the economic freedom indicators are lagged five years to minimize endogeneity, thus limiting the risk of reverse causality to a minimum. Yet, while we believe there should be no serious concerns regarding causality, we acknowledge that it cannot be proven and therefore we should be cautious about it in the conclusions of this article.

Apart from the causality issue, we found evidence of heteroscedasticity. A reason for this is the occurrence of extreme observations for certain countries, which are most likely due to cultural and historical factors that cannot be measured and are country-specific. In 
order to deal with this we used robust standard errors for the calculation of the significance of the regression coefficients.

\section{Empirical Results}

In this section we present the results of our empirical analysis. First, the correlation coefficients will be reported in order to give an indication of how the dependent and independent variables are related to each other. Second, the multiple regression analysis will be presented. Third, we report the estimation results for the indirect effects of the various dimensions of economic freedom on life satisfaction, resulting from the mediation through income inequality.

\subsection{Bivariate Correlation Analysis}

Table 3 reports the results of bivariate correlation analysis.

Life satisfaction is positively related to the protection of property rights and freedom from regulation. It is negatively to fiscal freedom and positively to sound money, and free trade when measured by the Heritage Foundation. Net income inequality is strongly positively related to fiscal freedom while it correlates negatively with protection of property rights. In addition, it is also significantly negatively correlated with free trade when measured by the Fraser Institute, and with sound money when measured by the Heritage Foundation and positively to freedom from regulation. Gross income inequality is negatively related to fiscal freedom, while it correlates positively with free trade, and with the Fraser Institute's sound money and the Heritage Foundation's freedom from regulation.

\subsection{Multiple Regression Analysis}

Table 4 presents the results of the multiple regression analysis. The $p$ values of the Hausman test varied between 0.08 for gross Gini to 0.99 for net Gini, indicating that the random-effects model is the preferred model. Model 1 and 2 present the results when using the measure of economic freedom by the Fraser Institute and Heritage Foundation, respectively.

Columns 3 and 6 show that life satisfaction is significantly negatively related to the net Gini coefficient in both models. These results support hypothesis 6. The gross Gini coefficient is insignificant. This is in line with our expectations. ${ }^{3}$ For theoretical and empirical reasons, we therefore focus on the results for the net Gini coefficient.

\footnotetext{
3 The results for the control variables for life satisfaction are in line with earlier results of Ovaska and Takashima (2006) and Bjørnskov et al. (2008), except for monarchy and child mortality. Bjørnskov et al. (2008) found an insignificant effect for monarchy and a negative effect for child mortality. The positive effect of monarchy that we found is in line with the argument provided by Bjørnskov et al. (2008) that citizens living in monarchies will be more satisfied with their lives, because the monarch as head of state exerts unifying and stabilizing forces bridging ethnic fractionalization and differences in party ideologies. The positive effect for child mortality is, however, opposite to what one would expect. Possibly this positive effect reflects the influence of another, unknown, variable. A close look at the data showed that there is a steady downward trend in child mortality in all countries. This trend may correlate with the trend in another unknown variable that correlates also with life satisfaction. Further testing showed, for example, that child mortality is highly and significantly negatively related to the share of people aged 65 or older. If we replaced child mortality by the share of people aged 65 or older, we found that this variable has a significant negative effect on life satisfaction. This latter effect is in line with estimation results of Ovaska and Takashima (2006) who also found a significant negative effect of population ageing on life satisfaction.
} 


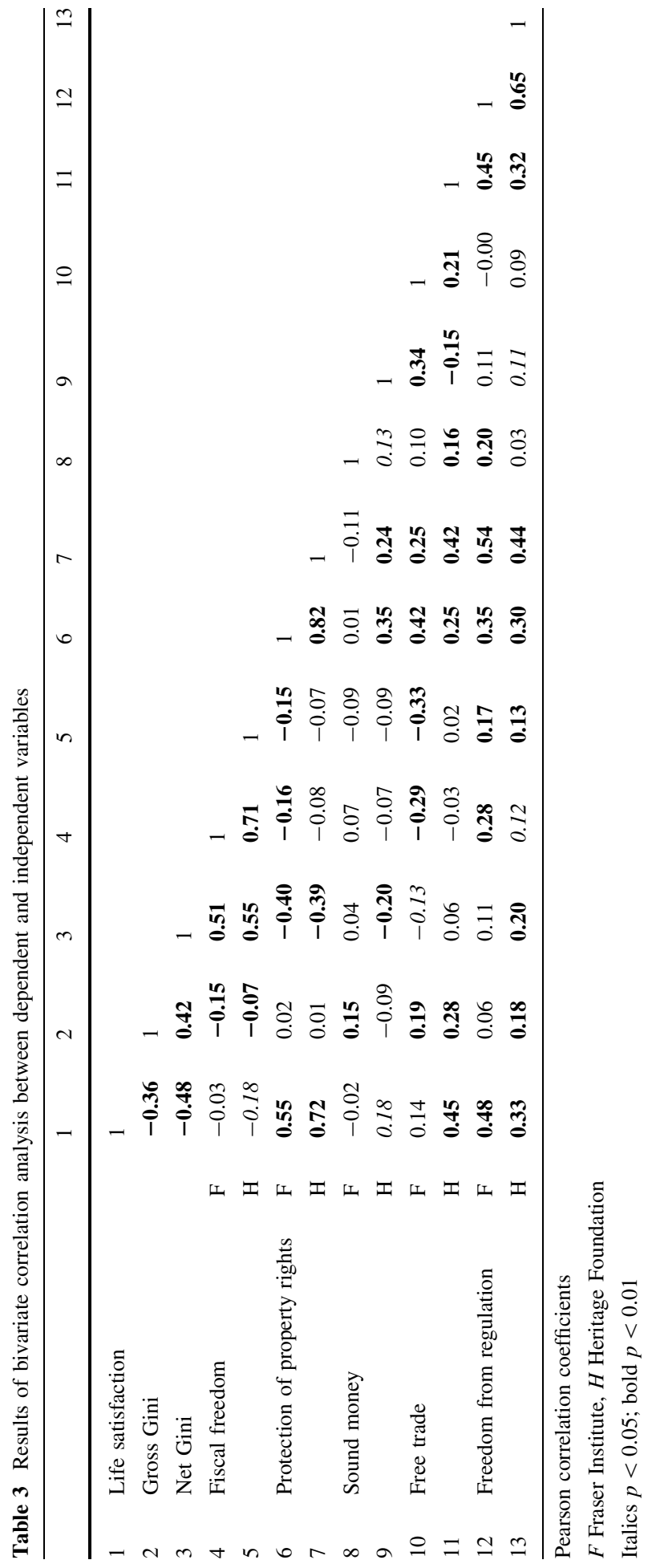


Table 4 Multiple regression analysis

\begin{tabular}{|c|c|c|c|c|c|c|}
\hline & \multicolumn{3}{|l|}{ Model 1} & \multicolumn{3}{|l|}{ Model 2} \\
\hline & $\begin{array}{l}1 \\
\text { Net Gini }\end{array}$ & $\begin{array}{l}2 \\
\text { Gross } \\
\text { Gini }\end{array}$ & $\begin{array}{l}3 \\
\text { Life } \\
\text { satisfaction }\end{array}$ & $\begin{array}{l}4 \\
\text { Net Gini }\end{array}$ & $\begin{array}{l}5 \\
\text { Gross } \\
\text { Gini }\end{array}$ & $\begin{array}{l}6 \\
\text { Life } \\
\text { satisfaction }\end{array}$ \\
\hline Net Gini & & & $-0.06 * * *$ & & & $-0.05^{* *}$ \\
\hline Gross Gini & & & -0.01 & & & -0.03 \\
\hline Fiscal freedom & $0.22 * *$ & $-0.96 * * *$ & & $0.46^{* * *}$ & $-1.09 * * *$ & \\
\hline Property rights & 0.30 & 0.37 & & $-0.46^{*}$ & 0.16 & \\
\hline Sound money & $-0.55 * * *$ & 0.71 & & $-0.65^{*}$ & $-1.36^{* *}$ & \\
\hline Free trade & $0.73 * *$ & $1.03 * *$ & & $1.03 * * *$ & $0.85 * *$ & \\
\hline $\begin{array}{l}\text { Freedom from } \\
\text { regulation }\end{array}$ & $0.86^{* * *} *$ & 0.28 & & $0.65 * * *$ & $0.40 *$ & \\
\hline Christian & $0.05 * * *$ & $0.10^{* * *}$ & 0.00 & $0.04 * * *$ & $0.06^{* * *}$ & $0.005^{*}$ \\
\hline Muslim & $-0.71 * * *$ & $-1.04 * * *$ & -0.04 & $-0.69 * * *$ & $-1.03 * * *$ & -0.03 \\
\hline Female participation & $-0.05^{*}$ & $0.17 * * *$ & $0.02 * *$ & -0.01 & $0.15^{* *}$ & $0.02 * *$ \\
\hline Political rights & 0.80 & $-2.12 *$ & -0.31 & -0.02 & $-3.53 * * *$ & -0.41 \\
\hline Civil liberty & $0.92 *$ & 0.95 & -0.10 & -0.19 & 0.45 & -0.08 \\
\hline Industrial sector & $-0.18 * * *$ & $-0.24 * * *$ & & $-0.08 * *$ & $-0.16^{*}$ & \\
\hline Age structure & -0.02 & $0.54 * * *$ & & 0.06 & $0.70 * * *$ & \\
\hline Openness & $-0.08 * * *$ & -0.01 & & $-0.08 * * *$ & $-0.03 *$ & \\
\hline Part time work & 0.00 & 0.01 & & -0.01 & 0.02 & \\
\hline Urbanization & -0.01 & -0.02 & & -0.00 & $-0.13 * * *$ & \\
\hline $\begin{array}{l}\text { Foreign direct } \\
\text { investment }\end{array}$ & -0.01 & -0.05 & & 0.01 & -0.01 & \\
\hline Nordic & $-5.57 * * *$ & $-8.39 * * *$ & & $-5.25 * * *$ & $-6.08 * * *$ & \\
\hline Ln GDP/cap & & & $1.36 * * *$ & & & $1.36 * * *$ \\
\hline Child mortality & & & $0.22 * * *$ & & & $0.22 * * *$ \\
\hline Temperature & & & -0.00 & & & -0.01 \\
\hline Inflation & & & -0.04 & & & -0.04 \\
\hline Unemployment & & & 0.00 & & & 0.00 \\
\hline Monarchy & & & $0.26^{* *}$ & & & $0.29 * * *$ \\
\hline $\mathrm{N}$ & 203 & 203 & 169 & 250 & 250 & 169 \\
\hline Wald $\mathrm{Chi}^{2}$ & 7593.08 & & & 7652.16 & & \\
\hline $\mathrm{R}^{2}$ & 0.87 & 0.76 & 0.62 & 0.89 & 0.75 & 0.62 \\
\hline Hausman $p$ value & 0.32 & 0.08 & 0.42 & 0.99 & 0.24 & 0.42 \\
\hline
\end{tabular}

Heteroscedasticity adjusted standard errors

$* p<0.05 ; * * p<0.01 ; * * * p<0.001$

Column 1 shows that the net Gini coefficient is positively related to tax freedom, trade freedom and freedom from regulation and negatively related to sound money. Only property rights is insignificant. If we use data from the Heritage Foundation (column 4), we find similar results. Again the net Gini coefficient is found to be the relevant indicator for income inequality in the regression analysis of life satisfaction. But, in contrast to the 
Table 5 Sobel test on mediation of influence of economic freedom on life satisfaction through net Gini coefficient income inequality

\begin{tabular}{lllll}
$\begin{array}{l}\text { Fiscal } \\
\text { freedom }\end{array}$ & $\begin{array}{l}\text { Protection } \\
\text { of property } \\
\text { rights }\end{array}$ & $\begin{array}{l}\text { Sound } \\
\text { money }\end{array}$ & Free trade & $\begin{array}{l}\text { Freedom from } \\
\text { regulation }\end{array}$ \\
\hline
\end{tabular}

\begin{tabular}{lcccc} 
Fraser Institute & & & & \\
Net Gini $-0.015^{* *}$ & -0.020 & $0.038^{* *}$ & $-0.050^{* *}$ & $-0.058^{* * *}$ \\
Heritage Foundation & & & & \\
Net Gini $\quad-0.028^{* *}$ & $0.027^{*}$ & 0.039 & $-0.060^{* * *}$ & $-0.038^{* *}$ \\
\hline
\end{tabular}

$* p<0.05 ; * * p<0.01 ; * * * p<0.001$

results in column 1, column 4 shows that the net Gini coefficient is also negatively related to the protection of property rights. Hence, in model 2 all six hypotheses are supported by the findings. ${ }^{4}$

\subsection{Mediation Tests}

In this section, we test the significance of the Gini coefficient as mediator in the relationship between economic freedom and life satisfaction. First, we re-estimated the model by dropping gross Gini coefficient. Then we used the Sobel test for panel analysis as proposed by Antonakis. ${ }^{5}$ The Sobel test is a method to test the strength of mediation of the effect of one variable on another through a third variable. It is a special form of the t-test that compares the magnitude of the indirect effect to the estimated standard error of the coefficients of the mediation path. ${ }^{6}$ The results are reported in Table 5.

The figures reported in Table 5 indicate the (indirect) effect of the respective economic freedom variable on life satisfaction that is passed on by the net Gini coefficient. This indirect effect is equal to the multiplication of the direct effect of income inequality on life satisfaction (a in Eq. (1) above) and the effect of the respective economic freedom variable on income equality ( $\mathrm{d}_{\mathrm{i}}$ in Eq. (2) above). For example, as the effect of fiscal freedom on income inequality is 0.22 and the effect of income inequality on life satisfaction is -0.06 (see Table 4), the indirect effect is equal to -0.015 . Using the data from the Fraser Institute, we find that the net Gini coefficient significantly mediates the influences of fiscal freedom, sound money, free trade and freedom from regulation on life satisfaction. Using data from the Heritage Foundation the positive impact of sound money on life satisfaction is not significant, whereas the impact of protection of property rights is confirmed.

\footnotetext{
${ }^{4}$ With regard to the control variables for the net Gini coefficient, most effects are in line with the results in other literature, except for Christian, industrial sector and age structure. Bergh and Bjørnskov (2014) found different effects for different Christian religions (Catholic, Protestant and Orthodox), whereas Bennett and Nikolaev (2014) also found a negative, but insignificant, effect of industrial sector and a positive effect for age structure.

${ }^{5}$ http://www.stata.com/statalist/archive/2010-05/msg00673.html.

${ }^{6} \mathrm{t}=\mathrm{ad}_{\mathrm{i}} / \mathrm{SE}_{\mathrm{pi}}$. a is the coefficient of income inequality in the equation of life satisfaction (Eq. (1) above) and $\mathrm{d}_{\mathrm{i}}$ the coefficient of economic freedom indicator $\mathrm{i}$ in the equation of income inequality (Eq. (2) above). $\mathrm{SE}_{\mathrm{pi}}$ is the pooled standard error term defined as $\sqrt{ }\left(\mathrm{a}^{2} \sigma_{\mathrm{di}}^{2}+\mathrm{d}^{2} \sigma_{\mathrm{a}}^{2}\right)$ and $\sigma_{\mathrm{a}}^{2}$ is the variance of a and $\sigma_{\mathrm{di}}^{2}$ is the variance of $d_{i}$.
} 


\section{Discussion and Policy Implications}

This paper studies the role of income inequality in the relationship between economic freedom and life satisfaction. In the theory section we develop 6 hypotheses on the relationship between economic freedom, income inequality, and life satisfaction.

The most important finding is that income inequality has a significant negative impact on life satisfaction, which supports our core hypothesis, namely that income inequality reduces average life satisfaction (H6). In line with theory, it is the net Gini coefficient that depresses life satisfaction, rather than the gross Gini coefficient. Furthermore, we find that net income inequality is positively related to fiscal freedom, free trade and freedom from government regulation and that sound money decreases income inequality, as hypothesized. These results are robust for the type of indicators used for economic freedom (Fraser Institute or Heritage Foundation). If we use the economic freedom data of Heritage Foundation, we also find support for the hypothesis that the protection of property rights decreases income inequality. Thus, from the six hypotheses, five to six hypotheses are confirmed, dependent on which data we use for economic freedom.

These findings support the idea that a radical free market economy may have negative effects on life satisfaction by enhancing income inequality. Overall, our results therefore confirm the theoretical analysis of economists such as Piketty, Stiglitz, and of other scientists like Wilkinson and Pickett, as well as of a number of recent papers on the importance of inequality. The policy implications are potentially far reaching and challenge the neo-liberal economic philosophy. However, it should be noted that income inequality is not the only channel through which economic freedom affects life satisfaction. Research has shown that (several dimensions of) economic freedom generate positive effects on life satisfaction by fostering economic growth and related socio-economic outcomes, such as trust (Hall and Lawson 2014; Graafland and Compen 2015).

One of the limitations of our study concerns the causality regarding the relationship between economic freedom and income inequality. While we used lagged variables of economic freedom and the (empirical) literature gives no reason to be concerned, we should be careful in making hard claims of causality. Future research should try to find proper instrumental variables to further test the causality between economic freedom and income inequality.

Furthermore, for future research, the data from the World Top Income Database of the Paris School of Economics provide an interesting opportunity to study the relationship between economic freedom and inequality in more detail and over a longer time period. This database will make it possible to further understand the phenomenon of inequality by focusing more on extreme inequality. Unfortunately, up till now the number of countries that have specific data on the (net) percentage share of income of different population groups is still limited. However, while our research indicates that economic freedom does have a diverse but significant impact on inequality as measured by the Gini coefficient, the impact can be expected to be even stronger when looking at the percentage income of the richest $10 \%$ of the population as well as of the richest 5 or $1 \%$.

Another extension of our research would be to study wealth inequality instead of income inequality. Piketty (2014) presumes wealth to be much more influential with respect to our economic and political system than income inequality, because wealth is passed on to future generations and thus ensures the continuation of privileges and strong social ties between especially the richest population groups. This would make it harder for newcomers to become important players, both in the economy and in politics. Besides 
these social effects of wealth, Piketty showed that wealth is distributed even more unequally than income, in some countries wealth inequality being twice as large as income inequality. A major drawback is that reliable data for wealth inequality are only available for a much more limited set of countries than the indicators for income inequality.

Open Access This article is distributed under the terms of the Creative Commons Attribution 4.0 International License (http://creativecommons.org/licenses/by/4.0/), which permits unrestricted use, distribution, and reproduction in any medium, provided you give appropriate credit to the original author(s) and the source, provide a link to the Creative Commons license, and indicate if changes were made.

\section{Appendix 1: Economic Freedom}

\begin{tabular}{|c|c|c|c|}
\hline \multicolumn{2}{|l|}{ Fraser institute $^{\mathrm{a}}$} & \multicolumn{2}{|c|}{ Heritage foundation $^{b}$} \\
\hline Fiscal freedom & $\begin{array}{l}1 \text { Fiscal freedom (top } \\
\text { marginal income rate and } \\
\text { payroll tax rate) }\end{array}$ & $\begin{array}{l}\text { Fiscal } \\
\text { freedom }\end{array}$ & $\begin{array}{l}\text { 1. Fiscal freedom (top tax rates on } \\
\text { individual and corporate incomes, } \\
\text { overall tax revenues as } \% \text { of GDP) }\end{array}$ \\
\hline $\begin{array}{l}\text { Legal system } \\
\text { and property } \\
\text { rights }\end{array}$ & $\begin{array}{l}\text { 1. Judicial independence } \\
\text { 2. Impartial courts } \\
\text { 3. Protection of property } \\
\text { rights } \\
\text { 4. Military interference in } \\
\text { rule of law and politics } \\
\text { 5. Integrity of legal system } \\
\text { 6. Legal enforcement of } \\
\text { contracts } \\
\text { 7. Regulatory costs of the } \\
\text { sale of real property } \\
\text { 8. Reliability of police } \\
\text { 9. Business costs of crime }\end{array}$ & $\begin{array}{l}\text { Protection } \\
\text { of } \\
\text { property } \\
\text { rights }\end{array}$ & $\begin{array}{l}\text { 1. Scale of property rights protection } \\
\text { 2. Corruption perceptions index }\end{array}$ \\
\hline $\begin{array}{l}\text { Access to sound } \\
\text { money }\end{array}$ & $\begin{array}{l}\text { 1. Money growth } \\
\text { 2. Standard deviation of } \\
\text { inflation, } \\
\text { 3. Inflation most recent year } \\
\text { 4. Freedom to own foreign } \\
\text { currency accounts }\end{array}$ & $\begin{array}{l}\text { Monetary } \\
\text { freedom }\end{array}$ & $\begin{array}{l}\text { 1. Monetary freedom (price stability, } \\
\text { price controls) }\end{array}$ \\
\hline $\begin{array}{l}\text { Freedom to } \\
\text { trade } \\
\text { internationally }\end{array}$ & $\begin{array}{l}\text { 1. Tariffs } \\
\text { 2. Regulatory barriers } \\
\text { 3. Size of trade sector } \\
\text { relative to potential } \\
\text { 4. Black-market exchange } \\
\text { rates } \\
\text { 5. Controls of the movement } \\
\text { of capital and people }\end{array}$ & $\begin{array}{l}\text { Open } \\
\text { markets }\end{array}$ & $\begin{array}{l}\text { 1. Trade freedom } \\
\text { 2. Financial freedom } \\
\text { 3. Investment freedom }\end{array}$ \\
\hline $\begin{array}{l}\text { Freedom from } \\
\text { regulation }\end{array}$ & $\begin{array}{l}\text { 1. Credit market regulations } \\
\text { 2. Labor market regulations } \\
\text { 3. Business regulations }\end{array}$ & $\begin{array}{l}\text { Regulatory } \\
\text { efficiency }\end{array}$ & $\begin{array}{l}\text { 1. Labor freedom } \\
\text { 2. Business freedom }\end{array}$ \\
\hline
\end{tabular}

\footnotetext{
a Source: http://www.freetheworld.com/2015/economic-freedom-of-the-world-2015.pdf

b Source: http://www.heritage.org/index/about
} 


\section{Appendix 2: Number of Observations Per Countries Included in the Empirical Analysis}

\begin{tabular}{|c|c|c|c|}
\hline & \multicolumn{2}{|c|}{ Income inequality } & \multirow[t]{2}{*}{ Life satisfaction } \\
\hline & Fraser institute & Heritage foundation & \\
\hline \multicolumn{4}{|l|}{ North America } \\
\hline Canada & 5 & 5 & 2 \\
\hline United States & 10 & 13 & 6 \\
\hline \multicolumn{4}{|l|}{ Western Europe } \\
\hline Austria & 10 & 13 & 4 \\
\hline Belgium & 8 & 11 & 9 \\
\hline Denmark & 10 & 12 & 8 \\
\hline Finland & 11 & 12 & 11 \\
\hline France & 11 & 13 & 7 \\
\hline Germany & 10 & 13 & 13 \\
\hline Ireland & 9 & 12 & 6 \\
\hline Italy & 11 & 13 & 7 \\
\hline Netherlands & 11 & 12 & 9 \\
\hline Norway & 11 & 12 & 8 \\
\hline Portugal & 10 & 12 & 9 \\
\hline Spain & 10 & 13 & 11 \\
\hline Sweden & 11 & 13 & 10 \\
\hline Switzerland & 10 & 12 & 11 \\
\hline United Kingdom & 11 & 13 & 13 \\
\hline \multicolumn{4}{|l|}{ Asia and Oceania } \\
\hline Australia & 8 & 13 & 10 \\
\hline Japan & 6 & 9 & 5 \\
\hline New Zealand & 11 & 12 & 7 \\
\hline South Korea & 9 & 12 & 3 \\
\hline Total & 192 & 250 & 163 \\
\hline
\end{tabular}

As shown by this table, the data base is not completely balanced. However, missing values are rather infrequent. Moreover, since our sample is focused on OECD countries, it is likely that missing values are random. In order to test if the model is robust if the data base is more balanced, we also estimated the model with a data base excluding countries that have 6 or less observations for, respectively, income inequality and life satisfaction. The regression results did not change substantially, however (see Appendix 3) 


\section{Appendix 3: Estimation Results with More Balanced Sample}

\begin{tabular}{|c|c|c|c|c|}
\hline & \multicolumn{2}{|c|}{ Fraser institute } & \multicolumn{2}{|c|}{ Heritage foundation } \\
\hline & 1 Net Gini & $\begin{array}{l}4 \\
\text { Life satisfaction }\end{array}$ & $\begin{array}{l}5 \\
\text { Net Gini }\end{array}$ & $\begin{array}{l}6 \\
\text { Life satisfaction }\end{array}$ \\
\hline Net Gini & & $-0.08 * * *$ & & $-0.08 * * *$ \\
\hline Fiscal freedom & $0.22 * *$ & & $0.45 * * *$ & \\
\hline Property rights & 0.30 & & $-0.54 * *$ & \\
\hline Sound money & $-0.40^{* *}$ & & 0.04 & \\
\hline Free trade & $0.62 * *$ & & $0.61 * *$ & \\
\hline Freedom from regulation & $0.80 * * *$ & & $0.73 * * *$ & \\
\hline Control variables ${ }^{\mathrm{a}}$ & + & + & + & + \\
\hline $\mathrm{N}$ & 192 & 155 & 236 & 155 \\
\hline
\end{tabular}

${ }^{\text {a }}$ We controlled for all control variables reported in Table 3

\section{References}

Acemoglu, D. (2003). Patterns of skill premia. Review of Economic Studies, 70(2), 199-230.

Albanesi, S. (2002). Inflation and inequality. Discussion Paper No. 3470. Centre for Economic Policy Research.

Altman, M. (2008). How much economic freedom is necessary for economic growth? Theory and evidence. Economics Bulletin, 15, 1-20.

Apergis, N., Dincer, O., \& Payne, J. (2014). Economic freedom and income inequality revisited: Evidence from a panel error correction model. Contemporary Economic Policy, 32(1), 67-75.

Attanasio, O., Guiso, L., \& Jappelli, T. (1998). The demand for money, financial innovation, and the welfare cost of inflation: An analysis with households' data (p. w6593). No: National Bureau of Economic Research.

Baggio, J. A., \& Papyrakis, E. (2014). Agent-based simulations of subjective well-being. Social Indicators Research, 115, 623-635.

Barone, G., \& Mocetti, S. (2016). Inequality and trust: New evidence from panel data. Economic Inquiry, 54(2), 794-809.

Bastagli, F., Coady, D. \& Gupta, S. (2012). Income inequality and fiscal policy. IMF Staff Discussion Note SDN/12/08.

Beetsma, R. (1992). Essays on exchange rates and inflation. Doctoral dissertaion, Tilburg University.

Bennett, D., \& Nikolaev, B. (2014). On the ambiguous economic freedom-inequality relationship. SSRN 2467222 .

Bennett, D., \& Vedder, R. (2013). A dynamic analysis of economic freedom and income inequality in the 50 US States: Empirical evidence of a parabolic relationship. Journal of Regional Analysis \& Policy, $43(1), 42-55$.

Berg, A., \& Ostry, J. (2011). Inequality and unsustainable growth: Two sides of the same coin? IMF Staff Discussion Note SDN/11/08.

Berg, M., \& Veenhoven, R. (2010). Income inequality and happiness in 119 nations. In B. Greve (Ed.), Social policy and happiness in Europe (pp. 174-194). Cheltenham: Edgar Elgar.

Berggren, N. (1999). Economic freedom and equality: Friends or foes? Public Choice, 100(3-4), $203-223$.

Berggren, N., \& Jordahl, H. (2005). Does free trade really reduce growth? Further testing using the economic freedom index. Public Choice, 122(1-2), 99-114.

Berggren, N., \& Jordahl, H. (2006). Free to trust: Economic freedom and social capital. Kyklos, 59(2), $141-169$.

Bergh, A., \& Bjørnskov, C. (2014). Trust, welfare states and income equality: Sorting out the causality. European Journal of Political Economy, 35, 183-199.

Bjørnskov, C., Dreher, A., \& Fischer, J. A. V. (2007). The bigger the better? Evidence of the effect of government size on life satisfaction around the world. Public Choice, 130, 267-292. 
Bjørnskov, C., Dreher, A., \& Fischer, J. (2008). Cross-country determinants of life satisfaction: Exploring different determinants across groups in society. Social Choice and Welfare, 30(1), 119-173.

Bjørnskov, C., Dreher, A., \& Fischer, J. (2010). Formal institutions and subjective well-being: Revisiting the cross-country evidence. MPRA Paper No. 17159.

Blanchflower, D. G., \& Oswald, A. J. (2011). International happiness. NBER Working Paper Series, No. 16668.

Carter, J. (2006). An empirical note on economic freedom and income inequality. Public Choice, 130, $163-177$.

Cornia, G. A. (Ed.). (2004). Inequality, growth and poverty in an era of liberalization and globalization. Oxford: Oxford University Press.

Dawson, J. W. (1998). Institutions, investment, and growth: New cross-country and panel data evidence. Economic Inquiry, 36, 603-619.

De Haan, J., Lundström, S., \& Sturm, J. E. (2006). Market-oriented policies and economic growth: A critical survey. Journal of Economic Surveys, 20(2), 157-192.

De Haan, J., \& Sturm, J. E. (2000). On the relationship between economic freedom and economic growth. European Journal of Political Economy, 16(2), 215-241.

De Vanssay, X., \& Spindler, Z. (1994). Freedom and growth: Do constitutions matter? Public Choice, 78(3-4), 359-372.

Di Tella, R., \& MacCulloch, R. (2010). Happiness adaptation to income beyond 'Basic Needs'. In E. Diener, J. Helliwell, \& D. Kahneman (Eds.), International differences in well-being (pp. 217-247). New York: Oxford University Press.

Diener, E., Ng, W., Harter, J., \& Arora, R. (2010). Wealth and happiness across the world: Material prosperity predicts life evaluation, whereas psychosocial prosperity predicts positive feeling. Journal of Personality and Social Psychology, 99, 52-61.

Diener, E., \& Suh, E. (1997). Measuring quality of life: Economic, social, and subjective indicators. Social Indicators Research, 40(1-2), 189-216.

Dincer, O., \& Gunalp, B. (2012). Corruption and income inequality in the United States. Contemporary Economic Policy, 30(2), 283-292.

Dolan, P., Peasgood, T., \& White, M. (2008). Do we really know what makes us happy? A review of the economic literature on the factors associated with subjective well-being. Journal of Economic Psychology, 29, 94-122.

Easterlin, R. A., McVey, L. A., Sawangfa, O., Switek, M. S., \& Zweig, J. S. (2011). The happiness-income paradox revisited. IZA Discussion Paper Series, No 5799.

Easterly, W., \& Fischer, S. (2001). Inflation and the Poor. Journal of Money, Credit and Banking, 33(2), $160-178$.

Elgar, F., \& Aitken, N. (2011). Income inequality, trust and homicide in 33 countries. European Journal of Public Health, 21(2), 241-246.

Erosa, A., \& Ventura, G. (2002). On inflation as a regressive consumption tax. Journal of Monetary Economics, 49(4), 761-795.

Fischer, C. S. (2008). What wealth-happiness paradox? A short note on the American case. Journal of Happiness Studies, 9, 219-226.

Frey, B., \& Stutzer, A. (2001). What can economists learn from happiness research? CESifo Working Paper, No. 503.

Goldberg, P. K., \& Pavcnik, N. (2007). Distributional effects of globalization in developing countries. Journal of Economic Literature, 45, 39-82.

Graafland, J. J., \& Compen, B. (2015). Economic freedom and life satisfaction: Mediation by income per capita and generalized trust. Journal of Happiness Studies, 16(3), 789-810.

Gropper, D. M., Lawson, R. A., \& Thorne, J. T., Jr. (2011). Economic freedom and happiness. Cato Journal, $31,237-255$.

Gwartney, J., Holcombe, R., \& Lawson, R. (2004). Economic freedom, institutional quality, and crosscountry differences in income and growth. Cato Journal, 24, 205-233.

Gwartney, J., Lawson, R., \& Block, W. (1996). Economic freedom of the world: 1975-1995. Vancouver, BC: Fraser Institute.

Hajdu, T., \& Hajdu, G. (2014). Reduction of income inequality and subjective well-being in Europe. Economics: The Open-Access, Open Assessment E-Journal, 8, 2014-2035.

Hall, J. C., \& Lawson, R. A. (2014). Economic freedom of the world: An accounting of the literature. Contemporary Economic Policy, 32(1), 1-19.

Haltiwanger, J., Kugler, A., Kugler, M., Micco, A., \& Pages, C. (2004). Effects of tariffs and real exchange rates on job reallocation: Evidence from Latin America. Journal of Policy Reform, 7(4), 191-208. 
Helliwell, J. F. (2003). How's life? Combining individual and national variables to explain subjective wellbeing. Economic Modelling, 20, 331-360.

Helliwell, J. F. (2006). Well-being, social capital and public policy: What's new? The Economic Journal, 116, C34-C45.

Helliwell, J. F., Barington-Leigh, C. P., Harris, A., \& Huang, H. (2009). International evidence on the social context of well-being. NBER Working Paper Series, No. 14720.

Jäntti, M., \& Jenkins, S. (2010). The impact of macroeconomic conditions on income inequality. Journal of Economic Inequality, 8, 221-240.

Justesen, M. K. (2008). The effect of economic freedom on growth revisited: New evidence on causality from a panel of countries 1970-1999. European Journal of Political Economy, 24, 642-660.

Kahn, R. S., Wise, P. H., Kennedy, B. P., \& Kawachi, I. (2000). State income inequality, household income, and maternal mental and physical health: Cross sectional national survey. British Medical Journal, 321, 1311-1315.

Leigh, A. (2006). Trust, inequality and ethnic heterogeneity. Economic Record, 82(258), 268-280.

Lerner, M. (2006). The left hand of god. New York: HarperOne.

Luttmer, E. F. P. (2005). Neighbors as Negatives: Relative Earnings and Well-Being. The Quarterly Journal of Economics, 120(3), 963-1002.

Mulligan, C. B., \& Sala-i-martin, X. (2000). Extensive margins and the demand for money at low interest rates. Journal of Political Economy, 108(5), 961-991.

Norberg, J. (2002). Till världskapitalismens försvar (B. de Koster, Trans.). Antwerpen/Amsterdam: Houtekiet.

OECD. (2012). Reducing income inequality while boosting economic growth: Can it be done? In P. C. Padoan (Ed.), Economic policy reforms 2012: Going for growth. Paris: OECD.

Oishi, S., Kesebir, S., \& Diener, E. (2011). Income inequality and happiness. Psychological Science, 22(9), 1095-1100.

Oshio, T., \& Kobayashi, M. (2010). Income inequality, perceived happiness, and self-rated health: Evidence from nationwide surveys in Japan. Social Science and Medicine, 70, 1358-1366.

Ostry, J., Berg, A., \& Tsangarides, C. (2014). Redistribution, inequality, and growth. IMF Staff Discussion Note SDN/14/02.

Ovaska, T., \& Takashima, R. (2006). Economic policy and the level of self-perceived well-being: An international comparison. Journal of Socio-Economics, 35, 308-325.

Piketty, T. (2014). Capital in the 21st century. London: Beldknap/Harvard.

Piketty, T., \& Saez, E. (2013). Top incomes and the great recession: Recent evolutions and policy implications. IMF Economic Review, 61(3), 456-478.

Porto, G. (2006). Using survey data to assess the distributional effects of trade policy. Journal of International Economics, 70(1), 140-160.

Roine, J., Vlachos, J., \& Waldenström, D. (2009). The long-run determinants of inequality: What can we learn from top income data? Journal of Public Economics, 93, 974-988.

Romer, C. D., \& Romer, D. H. (1998). Monetary policy and the well-being of the poor. In A. Greenspan (Ed.), Income inequality: Issues and policy options. Jackson Hole: Federal Reserve Bank of Kansas City.

Schmidt-Catran, A. W. (2014). Economic inequality and public demand for redistribution: Combining crosssectional and longitudinal evidence. Socio-Economic Review, 14(1), 119-140.

Schneider, S. (2012). Income inequality and its consequences for life satisfaction: What role do social cognitions play?. Social Indicators Research, 106, 419-438.

Schwarze, J., \& Härpfer, M. (2002). Are people inequality averse, and do they prefer redistribution by the state? Evidence from German longitudinal data on life satisfaction. IZA Discussion Paper No. 403.

Scully, G. W. (2002). Economic freedom, government policy and the trade-off between equity and economic growth. Public Choice, 113, 77-96.

Sedlacek, T. (2012). Economics of good and evil. Oxford: Oxford University Press.

Simic, M. (2012). A critical reading of The Spirit Level: Why equality is better for everyone. In R. Wilkinson \& K. Pickett (Eds.), CERES Department. Paris: Ecole Normale Supérieure.

Steijn, S., \& Lancee, B. (2011). Does income inequality negatively affect general trust? Examining three potential problems with the inequality/trust hypothesis. Gini Discussion Papers.

Stevenson, B., \& Wolfers, J. (2008). Economic growth and subjective well-being: Reassessing the Easterlin paradox. CESifo Working Paper, 2394.

Stiglitz, J. (2002). Globalization and its discontents. New York: Norton \& Company.

Stiglitz, J. (2012). The price of inequality. London: W. W. Norton \& Company.

Sturm, R., \& Gresenz, C. (2002). Relations of income inequality and family income to chronic medical conditions and mental health disorders: National survey in USA. British Medical Journal, 324, $20-23$. 
Veenhoven, R. (2000). Freedom and happiness. In E. Diener \& E. M. Suh (Eds.), Culture and subjective wellbeing (pp. 257-288). Boston: MIT Press.

Verme, P. (2011). Life satisfaction and income inequality. Review of Income and Wealth, 57(1), 111-137.

Wilkinson, R., \& Pickett, K. (2009). Income inequality and social dysfunction. Annual Review of Sociology, 35, 493-511.

Wilkinson, R., \& Pickett, K. (2010). The spirit level: Why equality is better for everyone. London: Penguin Books.

Wood, A. (1999). Openness and wage inequality in developing countries: The Latin American challenge to east Asian conventional wisdom. In R. Baldwin et al. (Eds.), Market integration, regionalism and the global economy (pp. 153-181). Cambridge: Cambridge University Press.

World Bank. (2006). World development report 2006. Washington, DC: World Bank.

Zagorski, K., Evans, M., Kelley, J., \& Piotrowska, K. (2014). Does national income inequality affect individuals' quality of life in Europe? Inequality, happiness, finances, and health. Social Indicators Research, 117, 1089-1110. 